NBER WORKING PAPER SERIES

CORPORATE SAVINGS AND SHAREHOLDER CONSUMPTION

Alan J. Auerbach

Kevin Hassett

Working Paper No. 2994

NATIONAL BUREAU OF ECONOMIC RESEARCH

1050 Massachusetts Avenue

Cambridge, MA 02138

Jume 1989

We are grateful to the NBER and the NSF for financial support, and to Angus Deaton, Tarhan Feyzioglu, Fumio Hayashi, Greg Mankiw, John Shoven, Joel Slemrod, members of the NBER's program in Financial Markets and Monetary Economics, and particlpants in workshops at Columbia Business School and Wharton for comments on an earlier draft. The second author acknowledges the support of a sloan Foundation dissertation fellowship. This paper is part of NBER's research program in Financial Markets and Monetary Economics. Any opinions expressed are those of the authorg not those of the National bureau of Economic Research. 


\section{NBER Working Paper \#2994}

June 1989

CORPORATE SAVINGS AND SHAREHOLDER CONSUMPTION

\section{ABSTRACT}

This paper reexanines the Implications of changlng corporate savings, testing for the presence of a "corporate vell". We argue that previous tests for such a veil have lacked proper focus, identfying fnfluences of corporate saving on private saving that are entirely consistent with a complete piercing of the corporate veil.

We formulate two tests. Results based on the flrst find that wealth-neutral changes in corporate dividend policy do not significantly affect aggregate consumption, suggesting that no corporate veil exists. The second test finds the aggregate consumption response to changes in corporate wealch is close to zero, consistent with the presence of a veil but also with heterogeneity in the population with respect to consumption behavior.

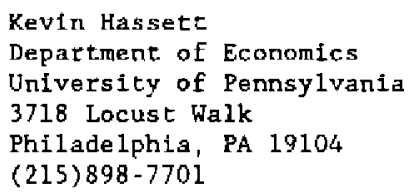

\author{
Alan J. Auerbach \\ Department of Economics \\ University of Eennsylvania \\ 3718 Locust Walk \\ Philadelphia, PA 19104 \\ (215) $898-1503$
}




\section{Introduction}

The 1986 Tax Reform Act markedly altered the relative tax burden of corporations and individuals while also changing the incentives for corporate dividend distribucions. Over the period 1987-91, corporate tax revenues were projected to rise by 120.3 billion dollars, with individual taxes being reduced by 121.9 billion dollars. 1 The act also repealed the $60 \mathrm{z}$ exclusion previously afforded capttal gains and raised the top marginal tax race from a high of 208 to a high of 338 . At the same time the top rate on dividends was cut from 50 s to 338 .

The shift in after tax income from corporations to individuals combined with the increased tax incentive to pay dividends has led some to predict profound reductions in corporate savings. Since corporate savings typically account for over half of private savings, this has prompted concern that aggregate capital accumulation will be adversely affected. Indeed, a recent Data Resources Inc. publication predicts that:

"Private Savings are likely to decline because of the massive shift of post tax income from businesses to Individuals... over the 1986-91 interval, personal savings are thus expected to be only $\$ 5$ billion higher while corporate savings are $\$ 24$ billion lower." 2

This quote reflects the conception that the transfer of cash from corporations to shareholders will alter real activity, a view consistent with the 1mpression that shareholders do not "pierce the corporate veil" and recognize the full implications of the transfer. While the belief that transfers from corporations to Individuals will have signiflcant real effects may be commonly held, there is very weak supporting evidence for the proposition that pure transfer policies have any such effects.

This paper reexamines the implications of changlng corporate savings. We begin with the straightforward proposition that the outcome depends crucially on the consumption behavior of shareholders. If, holding wealth constant, 
shareholders are perfectly rational and recognize raductions in corporate savings as a change in their own asset position, then they will counteract any changes in corporate retentions with Increased personal savings, leaving private savings unchanged. It is this compensating response to wealth-neutral changes in corporate saving that we characterize as "plercing" the corporate veil. We use this simple observation about shareholder savings to develop a new test for the existence of the corporate veil.

The next section discusses the theory behlnd the corporate veil and argues that much of the previous l1terature lacked a proper focus. There are. several feasons why changes in corporate saving might be associated with changes in national saving that are entirely consistent with a complete plercing of the corporate veil. Section III outlines and presents an Euler equation test for the existence of the corporate veil. The test supports the hypothesis that no such vell exists. Although the test's power is not strong enough to reject certaln plausible alternative hypothesis, this finding scill casts doube on previous results purporting to demonstrate the existence of a corporate veil.

Because the Euler equation test is not powerful enough, by itself, to dispose entirely of the possible existence of a corporate veil, we then consider other approaches to the question. Using a switching regressions model of consumption based on the Euler equation, we show in section IV that the observed signtficant excess sensitivicy of consumption to predictable changes in disposable income is assoclated with liquldity constraints, rather than myopia or 1rrational behavior. This 1s further evidence against the existence of a corporate ve11, because such liquidity constraints are almost certain not to apply to consumption supported by corporate wealth. Section $V$ uses recent advances in the theory of cointegrated processes to shed new light 
on the time series propertes of consumption behavior and evaluate subtler tests for the presence of the corporate vell. A signiflcant finding in this section is that the aggregate marginal propensity to consume out of corporate wealth is considerably lower than that from other tangible wealth. This could be associated with a corporate vell, or with marglnal consumpton propensities differing across households according to wealth. Section VI concludes the paper.

Because the prevlous literature has often been obscure on this point, it is useful to provide at the outset a preclae statement of what a corporate veil would do. Our view is that a corporate vell would exist if a shift in the distribution of an individual's wealth among corporate and noncorporate forms, holding his overall wealth constant, affected that 1ndividual's consumption. We therefore rule out changes in relative asset values that also affect aggregate vealth or the distribution of aggregate wealth anong individuals as useful in the search for a corporace vell.

As we shall discuss, tax-Induced changes in corporate behavior can affect indfuidual consumption behavior without a corporate veil: these policies could alter the overall value of private assers or the distribution of wealth among individuals.

\section{The Corporate VeI1}

Reductions in corporate savings need not, of course, Imply lower aggregate private savings. Corporate savings can be thought of as that investment which is financed out of retained earnings, rather than with new debt or equity. Under certain well specifled conditions, this should, as first noted by Modigliani and Miller (1958) and Miller and Modigliani (1961), be of no consequence to the value of the firm. Any Increase in dividends can 
simply be offset by a commensurate fncrease in the firm's debt or issues of new equity. The Modigllani-Miller analysis will hold in general equilibrium, provided that dividend reciplents recognize that their apparent windfall is merely a time reallocation of their asset's dividend stream. Under perfect markets, consumption will not be altered, because the consumer's optimization problem is unchanged. Real behavior will not be affected by a financial version of musical chairs.

This "dfvidend irrelevance" view relfes upon the shareholder's ability to "pierce the corporate veil", 1,e., to recognize wealth neutral changes in financial policy for what they are. It further requires that shareholders can act to offset corporate savings decisions. If shareholders were liquidity constrained, then an lncrease in corporate digtributions would relax this constraint and increase consumption, even with no change in perceived shareholder wealth. The case is analogous to consumption increasing without a change in human wealth if current labor Income increases. However, there are two significant differences between the two cases. First, shareholders can sell stock or borrow against it to relax liquidity constraints, while such transactions are severely linfted with respect to human capital. Second, as we discuss further below, the distribution of share ownership is 50 concentrated among wealthy individuals that the aggregate importance of liquidity constraints within this group is implausible.

If the value of the firm increaseg because of some underlying change in fundamentals, then a significant share of the concomitant increase in dividends may be consumed because the wealth or permanent income of the shareholder has 1ncreased. If, on the other hand, firm reduces retained earnings and increases dividends by one dollar without any underlying change in the firm's real prospects, then, according to the permanent income 
hypothesis, consumption will not change in the absence of taxes because toral vealth remains the same. ${ }^{3}$ When markets are perfect, financial structure, or equivalently, the timing of dividends, should have no effect on real economic behavior. This distinction is cruclal to the proper understanding of the "corpotate velI", and has been overlooked by much of the previous literature, which seems to interpret consumption responses to fluctuating dividends as evidence of a shareholders inability to see through the corporate veli. To the extent that changes in dividends reflect real changes in the value of the firm, as Indeed signalling models would suggest, consumption will, of course, change.

This point lends an interesting perspective to the quote on page one. There, the shift in post tax income from corporations to Individuals, in the aggregate very close to a vealth neutral transfer, is predicted to reduce aggregate savings by 19 billion dollars! This view suggests that simply carrying wealth acrogs the corporate threshold induces massive changes in the consumption behavior of shareholders. Since it is implauslble that liquidity constraines could explain so large a shift in shareholders" consumption, some other force must be perceived as operating here.

Proponents of this view may simply believe that some fundamental shareholder irrationality exists. Alternatively there way be a different experiment being implicitly consldered, one that does not preserve the initial distribution of wealth among individuals. Changes in the distribution of wealth could well alter aggregate consumption, but one needs no corporate veil to explain such effects. ${ }^{4}$ A problem one has in interpreting statements relating corporate and personal saving is that the experiment being envisioned is not explicitly specified. This vagueness has permeated the statistical evidence attempting to relate corporate and personal saving, in effect 
veiling the corporate veil.

The modern empirical study of corporate saving can be traced back to Denison (1958), who found that private saving was much smoother than its components, suggesting that personal and corporate saving may offset each other. Feldstein (1973) extended the inquiry by emphasizing that rational consumers should recognize retalned earnings as wealth accruals and consume from them. Using a traditional consumption function, Feldstein found that retaithed earnings were significanty positively correlated with consumption. He interpreted this as evidence that consumers pierce the corporate vell. Subsequent research has come down on both stdes of the issue. ${ }^{5}$ An exemple of recent work finding evidence of a corporate veil is Poterba (1987). Poterba regressed private saving on several macroeconomic indicators and a dividend tax preference variable. A negative and significant coefficient on dividend taxes was interpreted as evidence that consumers don't completely offset changes in corporate saving induced by tax-related changes in dividend policy. A second test using dividend taxes as an instrument for changes in corporate savirg, in an attempt to isolate wealth-neutral changes, found corroborative evidence. Since we have no a priorl reason to belleve that dividend taxes are orthogonal to wealth, Poterba's results are difficult to interpret.

Reexamination of the empirical methods used In existing studies of corporate saving reveals many shorteomings. Perhaps most importane, previous studies have falled adequately to describe consumer behavior consistent with shareholder rationality. Because of this there has been an improper focus on simple changeg in dividends or retafned earnings, which are certainly correlated with changes in wealth. The response of consumption to these can not be interpreted as a violation of the permanent income hypothesis and, as such, is irrelovant to the Investigation of the existence of a corporate vail. 
In addition, by neglecting the duality of consumption and savings, some studies have needlessly introduced problems of measurement error as researchers have struggled over proper definitions for personal and private savings. ${ }^{6}$ This focus on saving has also divorced the inquify from breakthroughs in the study of consumer behavior and rational expectaclons which, as we shall illustrate, are particularly useful here.

Another problem with some previous research 1 from an econometric viewpoint. Results typically based on regresstons ustng levels of aggregate time series are difflcult to interpret because of underlyling nonstationarity and the well known accompanying spurious regression difficultes. ${ }^{7}$

Significant correlation between corporate retained earnings or dividends and consumptor: may simply reflect common trends in the data.

In the following sections we fllustrate that all of these shortcomings can be addressed through a straightforward application of the modern theory of the rational consumer. We test two related propositions implied by the absence of a corporate veil; first, that changes in dividend policy that are antlefpated, and hence provide no new information to shareholders in estimatirg their wealth, do not affect aggregate consumption; second, that the response of changes in consumption to changes in different forms of wealth (corporate versus noncorporate) are equal. Each test $1 \mathrm{~s}$ based on the idea that. In the absence of a corporate ve1l, shift in wealth should not affect consumption.

\section{II . Eller Equations and the Corporate Veil}

\section{A. Rational Expectations and the Theor of the Consumer}

Assuming a constant real interest rate and quadratic utility, Hall

(1978) showed that one Implication of the permanent income hypothests is that 
consumption follows a rendom walk. If rational agents maximize a time-separable function of consumption then all currentiy available Information will already be included in current consumption. Hence, current consumption should provide the best avallable forecast of future consumption. Subsequent generalizations to allow for interest rates that change over time.

Following the previous literature (e.g. Grossman and Shiller 1981. Hansen and Singleton 1983), consider a representative agent seeking to maximlze the expected utility of consumption. If this consumer has a CES utilfty function with an intertemporal elasticity of substitution $a$ and a pure rate of time preference $\delta$, then this his oprlmal consumption path will abey the Euler equation:

$$
E\left[\left(\frac{C_{t}}{C_{t-1}}\right)^{\frac{1}{\sigma}}\left(\frac{1+\delta}{1+r_{t}}\right)\right]=1
$$

where $r_{t}$ is the after-tax rate of return to savings. Equation (1) may also be written:

$$
\left\langle\frac{c_{t}}{C_{t-1}}\right)^{\frac{1}{\sigma}}\left(\frac{1+\delta}{1+r_{t}}\right)-I+\varepsilon_{t}
$$

where ${ }_{t}$ is a stochastic term with conditional mean zero at time $t-1$.

Taking $\operatorname{logs}$ of both sides of (2), and fmposing the approximation that $\ln (1+x)=x$ for $x$ small, one obtains

$$
\Delta c_{t}=-\sigma \delta+\sigma r_{t}+\sigma t_{t}
$$

where $\Delta c_{t}-\ln C_{t}-\ln c_{t-1}$. Since $r_{t}$ and $E_{t}$ are potentially correlated, it is useful to decompose $I_{t}$ into an expected component $r_{t}^{e}$ uncorrelated with 
$\varepsilon_{t}$ and a "surprise" term $r_{t} \cdot r_{t}^{e}$, to obtain an estimable equation ${ }^{8}$

$$
\begin{aligned}
\Delta c_{t} & =-\sigma \delta+\sigma r_{t}^{e}+\sigma\left(c_{t}+r_{t}-r_{t}^{e}\right) \\
& =\mu+\sigma r_{t}^{e}+e_{t}
\end{aligned}
$$

Much recent debate has focused on the observation of Flavin (1981) that consumption geems excessively sensitive to anticipated changes in income, which have a positive and significant effect when fncluded in equation 1. Interpretations of this positive coefficient have emphasized the idea that some fraction of consumers face liquidicy constralnts and consume their income in each perlod. To aid in th1s interpretation, Campbell and Mankfw (1987) consider a general model where $\lambda$ individuals are liquidty constrained. "Keynesian" consumers, and $(1 \cdot \lambda)$ individuals obey the permanent income hypothesis. In this case, if $\Delta y_{t}^{e}$ is defined to be the expected current change in the logarfthm of incowe of the liquidity-constrained group, equation (4) can be rewritten:

$$
\begin{gathered}
\Delta c_{t}-\lambda \Delta y_{t}^{e}+(1-\lambda)\left[\mu+\sigma r_{t}^{e}+e_{t}\right] \\
=\mu^{\prime}+\sigma^{\prime} r_{t}^{e}+\lambda \Delta y_{t}^{e}+e_{t}^{\prime}
\end{gathered}
$$

The implications of the permanent income hypothesis are straightforward in this context. Invoking rational expectations, 1.e., fngtrumenting with variables in the information set at the beginning of period $t$, should yield an estimate of $\lambda$ insignificantly different from zero. Noting that, as first pointed out by Working (1960), time aggregation could Induce an MA(1) error in equation 2 , making period $t-1$ varlables inadmissable as instruments, Campbell 
and Mankiw use twice lagged varlables as Instruments to obtain estimates of $\lambda$ ranging from .413 to .668 . They conclude that roughly 50 of of income is held by consumers who face liquldity constraints.

Simflar reasoning can be applied to consumers as stockholders.

Predictable changes in dividends, already in the current information set, should be incorporated into consumption plans. Thus, expected dividends should affect only the consumption of the liquidity-constrained. If we divide the income of liquidity constrained households $Y_{t}$ into dividend income $D_{t}$ and all other income $Y_{t^{\prime}}^{\star}$ then, In logarithms, $\Delta y_{t}=(1-\gamma) \Delta y_{t}^{*}+\gamma \Delta d_{t}$, where $\gamma$ is the proportion of total income that dividends represent for these households. Thus, equation (5) may be rewritten:

$$
\Delta c_{t}-\mu^{2}+\sigma^{\prime} \tau_{t}^{e}+\lambda_{1} y_{t}^{*_{e}^{e}}+\lambda_{2} \Delta d_{t}^{e}+e_{t}^{\prime}
$$

where $\lambda_{1}-\lambda(1 \cdot \gamma)$ and $\lambda_{2}-\lambda \gamma$.

The notion that liquidity congtraints can be significant in explaining consumption out of expected dividends is, as we suggested earlfer, difficule to support. Put simply, $\gamma$ must be very small. Row 1 of Table 1 , taken from the 1983 Survey of Consumer Finances, glves estimates of the proportion of corporate equities held by indfiduals in different strata of the Income distribution. ${ }^{9}$ Our measure of income Includes all money income recelved by the members of the sample in 1982. Notably, nearly all stock ownership is by those individuals at the top of the Income distribution, with almost 78 of all corporate wealth held by the top $5 \%$ of the income distribution. In addition, as mentioned before, if stockholders did face constraints they could easily relax thei by selling their stock.

Absent liquidity constraints, the coeffieient on expected dividends, $\lambda_{2}$, 
should be zero unless the corporate vell exists. Since expected changes in dividends are already included in agents' current fnferences about their asset positions, they should not affect consumption. ${ }^{10}$ This is true regardless of the tax treatment of those dividends, and whatever the process is that drives dividend changes. The coefflclent on dividends, $\lambda_{2}$, measures the response of consumption to percelved wealth neutral changes In dividends. If there is a corporate veil, this will be positive and significant.

As a final extension of the Euler equation approach we will further decompose disposable income into components attributable to capital and labor, keeping dividends separate. This will ald in the interpretation of excess sensitvity as liquidity constralnts in the form of an individual's inability to borrow against future labor income. The equation we estimate is:

$$
\Delta c_{t}-\mu^{\prime}+\sigma^{\prime} r_{t}^{e}+\lambda_{1} \Delta y l_{t}^{e}+\lambda_{2} \Delta y k_{t}^{e}+\lambda_{3} \Delta d_{t}^{e}+e_{t}^{\prime}
$$

To guard against a posstble aggregation induced first order moving average error term, we can estimate this equation using doubly lagged instrumental variables. 11

\section{B. The Data}

For our estimation we use quarterly and annual data from 1948-85 taken Exom the Citibase dataset. For consumption, we use aggregate consumpeion of nondurables and services. Our interest rate variable is the average 6-month Treasury bill rate for the quarter less the inflation rate based on the implicit price deflator for nondurable consumption. 12 Income is defined as aggregate disposable income and excludes after-tax dividends when these are included in the Euler equation. After-tax aggregate labor 1ncome, capital 
income and dividends are constructed in a manner similar to thar used by Blinder and Deaton (1985). Varfables are converted to real values with the aggregate deflator for nondurable consumption. Every varlable but the interest rate is in logs and per capita. Further discussion of the construction of our varlables is avallable in the appendix.

\section{Results}

We review first the results from our quarterly regressions. As a starting point, our estimation of equation 5 is reported in Table 2 , which raports the instrumental variable results based upon an instrument set which includes second, third and fourth lags of consumption and income the second lag of the six month T-bill rate, and second, third and fourth lags of pre-tax corporate profits and the after-tax return to shareholders of a dollar distributed versus a dollar retained, taken from Poterba (1987).13 our finding of a a Insigniflcantly different from zero agrees with results reported In Hall (1988), and Campbell and Manklw. Our estimate of $\lambda$ of .431 is very close to Campbell and Mankiw's reported estimates which range from .413 to .668 . The accompanying t-statistic 1s 3.56, implying that there is clear excess sensitivity of consumption to expected changeg in disposable income.

The estimates of equation 6 are reported in the second row of Table 2 , We use the same set of instruments but Include three lags of dividend changes, starting with the second lag. Again, our estimate of $\sigma$ is insigniflcantly dfferent from zero. Our estimate of $\lambda_{1}$ decreases slightly to .378 but is again statistically signiflcant. The estimate of $\lambda_{2}$, our measure of the corporate veil, is slightly positive but insigniflcantly different frow zero, Indicating that consumption is not excessively sensitive 
to dividends.

Equation 7, a further generalization of the Euler equation, is reported in the third row of Table 2. Again, second, third and fourth lags of the differenced variables and the second lag of the interest rate are used as instruments. Here, disposable income is broken down into its labor and capital components. The estimate of $\lambda_{1}$, interpretable as the proportion of labor income held by those who are liquidity constralned, is a statistically significant .458 . Both coefficients on eapital income are insignificantly different from zero, with the coefficlent on nondividend capital income equal to -.085 .

The annual results in Table 3 use the same specification, but are based on instrument sets including once-lagged varlables. We include such instruments because some variables are quite hard to predict using instruments lagged at least two years; our test of a corporate vell has little power unless a reasorable prediction of future dividend changes is possible. ${ }^{14}$

In comparing equations 5-7 in Table 3 to those in Table 2, we see few qualitative differences. The coefficients on disposable income are somewhat higher and those on dividends somewhat lower, but the conclusions are basically the same.

We have estimated these equations using different measures of the interest rate, different sets of instruments, different deflators, and different measures of consumption. In every case, we obtained results of a similar nature: we have found no evidence that consumption is excessively sensitive to changes in dividends, 1.e., no evidence of the existence of the corporate vell. In each case, the error is serially uncorrelated making the standard error estimates used to calculate the reported t-statistics admissible. 15 All of the variables used in the estimation are difference 
stationary, so no probleds of spurious regression are present.

How conclusive are these results concerning the existence of the corporate veil? The insigniflcance of the predicted changes in dividends is an important finding in light of previous claims to have "proved" the corporate veil's existence. The fact that predicted disposable labor income is consistently highly significant in these regressions while being no easier to predict shows that the Insignificance of dividends is not due stmply to the use of poor instruments. 16

Yet, one must recognize that the resules in Tables 2 and 3 are not powerful enough to reject all alternative hypotheses corresponding to the corporate vell. For example, under the alternative hypothesis that the same fractions of dividend income and labor income acerued to households facing liquidity constraints and having a marginal propensity to consume current income of unity, we would expect the coefficient on expected dividends, $\lambda_{2}$, to equal the fraction of consumption accounted for by such households, $\lambda$, multiplied by the ratio of dividends to disposable incowe. Since this ratio is of the same order of magnitude as the coefficlents of predicted dividends, we would be unable to reject the alternative hypothesis. We have already suggested, however, that there are fundamental inconsistencles with an alternative hypothesis based on liquidity constraints. The only plausible alternative must 1nvoke myopla or Irrationality to explain excess sensitivity. Thus, it $1 s$ important to determine the source of the documenced excess sensielvity of consumption to predictable changes in labor income. Unless a source compatible with the corporate vell is found, the results will support. our conclusion agalnst the veil's existence. 


\section{Credit Crises as Switching.Regressions}

As we have noted, there is more than one interpretation of the above result that consumption is excessively sensitive to changes in income. In this section we provide further evidence, based on a Markov switching model, that this excess sensitivity does Indeed reflect the impact of liquidity constraints. We flnd that excess sensftivity has been eplsodic and confined to a relatively small number of postwar years, typically during recessions and/or credit crises.

In their concluding remarks, Campbell and Mankiw remark that the violation of the Euler equation is only a recent phenomenon.

"The evidence against the permanent income model comes primarily from the second half of our sample period, 1969-85."17

Since a portion of this period is one of increased national debt and higher real interest rates, it is not lnconcelvable that borrowing behavior somehow changed after 1969 , but testing this is not gtraightforward, because, as Neftci (1984) noted, arbitrarily splitting data and testing for parameter differences may bias results in favor of finding aultiple parameter regimes. This observation suggests an alternative specification of the model of the consuner: we consider a model where all consumers consume according to the permanent income hypothesis, except for occasional surprise episodes of nonoptimal consumption caused by economy wide "credit crises". Specifically. we estlwace the following switching rodel:

$$
\begin{aligned}
\Delta c_{1 t}{ }^{*} & =a_{1} r_{1 t}^{e}+\lambda_{1} \Delta y_{1 t}^{e}+e_{i t} \\
\Delta c_{1 t} & =\Delta c_{1 t} t^{*} \text { if } 1-1 \\
& =\Delta c_{2 t}^{*} \text { if } 1-2
\end{aligned}
$$

where $c_{i t}$ is the logarithr of observed consumption, $r_{1 t}^{e}$ is the expected 
interest rate, $\Delta y_{i t}^{e}$ is the expected change in the logarithm income, and $e_{i t}$ are independent, normally distributed errors. If llquidity constraints only appear occagionally, there will be 2 distinct states. 18 The liquidity constralned state w11 have a large, positive and significant coefficlent on income. The unconstrained state will look like the random walk predicted by the permanent income hypothesis. Following Goldfeld and Quandt (1973) we godel the eransition from state 1 to state 2 as a first order Markov process.

Even with the simplifying Markov assumption, the likelihood function for this model is quite cumbersome, since the likelihood of each possible "trajectory" througi the data must be investigated. At first glance, this. seems to require the summation of $2^{t}$ terms in the calculation of the likelihood, something infeasible even in small samples. But, as Coslett and Lee (1985) have shown, the likelihood function can be rewritten using a recurrence relation which takes advantage of the assumed Markov structure and greatly reduces the computational burden. ${ }^{19}$ Even with this simplification, the model is a difficult nonlinear estimation problem, with the usual accompanying problem of possible local maxima and minima, To estimate the model we use the same data used in the above Euler equations, ${ }^{20}$ but in this case we use only annual data, since our earlfer results suggests that time aggregation will not alter the results significantly and the use of annual data further reduces the required computation time, since our analysis is only meant to be suggestive of the beneflts of this approach, we further simplify by approximating the expected interest rate with the actual lagged interest rate, and expected income with lagged income, rather than using instrumental variables. The Davidson Fletcher-Powell nonlinear search algorithm was used to find the optimum. Slnce the likelihood function is very nonlinear, and may have numerous local maxima, different starting values were 
tried in order to assure that the maximum attained is global. Finally, the Coslett-Lee algorithm was started up by assigning the initial probability of being in each state its unconditional value. ${ }^{21}$ The estimated matrix of second derivatives is used to construct the standard errors.

The results of the parameter estmation are reported in Table 4 . We find clear evidence of multiple regimes. In regime 1 , the unconstralned regime, our estimate of $\sigma$ is a statistically insignificant, 047 . The estimate of the coefficient on lagged changes in income is -.023, which is also insignificant. Sensitivicy to the interest rate is slightly higher in the second regime, with a ostiate of .082 , but this coefficient is, given its standard error, still Insignificantly different from zero. The liquidity constraint estimate for the second regime is .526 . The accompanying t-statfstic of 6.07 is significant at the .999 level of confidence. These estimates mesh quite well with previous estimates of the model's parameters, suggesting that our alternative nonlfnear (because of the interaction of the switching model and the linear consumption model) specification and our simplifying assumptions are reasonable. The estimated transition matrix and the accompanying t-statistics are also given in Table 4. Both regimes are signlficantly persistent. The probability of the economy being in the unconstrained state, given that it was unconstrained yesterday is .90 . The probability of moving from a constrained state to a constrained state $1 \mathrm{~s} .74$. These values imply an unconditfonal probability of belng in the constrained state of only .28 .

To galn further insight into the nature of the two regimes, we calculate the conditional inference of the probabllity that the current year is in the constrained reglme. The calculation of these probabilities follows the observation of Hamilton (1987), that time $t$ information can be combined with our inference about the Markov probabilities to construct the best estimate of 
the state of the world at time $t$, condltional on our best guess about the state of the world at $t-1$. For example, if the probability of befing in each state at time $t-1$ is .5 , and the transition probabilities are also .5, then the conditional probability of being in state 1 at time $t$ is simply the proportion of the total Iikelihood attributable to that state. If the Markov probabilities are different from .5, than the likelihoods are reweighed to account for the Markovian Information about the likelihood of each path through the data. If, for example, we have a strong inference that yescerday was in regime one, and the Markov probability of remaining in state 1 is very high, than we might classify today as regime 1 , even if the state 2 model appeared to fic the current observation better. Starting at time zero, a chain of successive inferences can be used to estimate the most likely trajectory taken through the two underlying models.

Table 5 contains the condftional state probability for each year. The probability estimates are in accordance with the view, expressed by Campbell and Mankiw, that liquidity constraints first emerged in that late 1960's. However, If we label a year a 'credit crisis year' if the probability of being In the constrained regime is greater than .5, then the first constrained year is 1966, not 1969, with the probability of being in the constrained regime being quite low before that and for sustained periods after 1970 as welI. After 1966, the economy switches periodically from constrained to unconstrained regime. Overall, only 10 years in our sample are in the constrained regine. Table 5, column 4 lists an alternative measure of credit tightness, the differential between the average and prime lending rates, on average, this is much larger during the "credit crunch" periods providing further indication that the credit crisis interpretation of liquidity constraints is valid. ${ }^{22}$ 


\section{A Iime Serles Invest 1 ration of Consumption from Assets}

\section{A. The Consumption Function and Cointeration}

In section II we showed that one Implication of the plercing of the corporate veil is that wealth neutral dividend changes should have no effect on consumption. Our findings in Section III conflymed the absence of any such effect. In section IV, we supported the plausibility of this result by demonstrating that the observed sensitivity of consumption to other forms of current income than dividends is attributable to liquidity constraints, which are very unlikely to apply to corporate shareholders.

This section considers another fmpllcation of shareholders piercing the corporate veil. We focus our attention on a question that was not easily addressed with our previous methodology: is the marglnal propensity to consume out of corporate wealth as high as the marginal propensity to consume out of other forms of wealth? A lower propensity to consume out of corporate wealth would imply a permanent increase in consumption as a result of a shift in resources from corporations to Individuals. This heterogeneity of response could be seen as evidence of a subtler form of corporate veil than we considered above. Our previous test found that a change in the portion of existing wealth held in corporate form does not affect consumption. Our new tests address whether the composition of changeg in wealth affect consimption. While such differences would be consistent with the presence of a corporate vell, there is at least one other potential explanation. Given the wealth distribution statistics reported in Table 1 , a lower aggregate marglnal propensity to consume out of corporate wealth would be consistent with a marginal propensity to consume declining with the overall level of wealth. In such a case, a weal th neutral transfer from corporations to individuals would increase consumption via distributional effects, not 
because of an effective corporate veil. This possibility is discussed further below.

The outcome of these new tests cannot be inferred directly from the Eindings to this polnt. For example, shareholders could understand and compensate for changes in dividend policy wh1le at the same time being more reluctant to rafse their consumpion to respond to increases in share prices. This reluctance could be attributable to a lack of faith in efficient markets, For example, a belief that a market that had risen might be above its "true" value.

This distinction helps to clarify the alternative possible sources of a corporate veil. We have already dismissed the idea that shareholders are afflicted by the "bird-in-the-hand" fallacy, that a dollar distributed by corporations is intrinsically more valuable once in their hands (holding taxes and other real differences constant). However, dividend policy is but one very simple mechanism by which corporate share values could change. Shareholders might be reluctant to respond to other changes in corporate wealth, as just suggested. Alternatively, they wight respond as we predict to changes in shareholder wealth, but the change in the market valuation of corporate shares may not accurately reflect "true" changes in corporace values. In either case, a corporate vell could exist, although by focusing on responses to changes in the market value of corporate wealth we do not consider the latter case.

To effect these alternative tests of the impact of corporate wealth on consumption, we take advantage of recent results concerning cointegrated time series.

One implication of the perwanent income hypothesis is that, holding interest rates constant, consumption is a constant fraction of wealth. The 
concept of wealth, of course, is total wealth, and includes the present discounted value of returns to human capital, human wealth. According to the theory, there should be an equilfbrium relationship between consumption and assets, or, In the terminology of Engle and Granger (1987). consumption and assets should be cointegrated. 23 The error term frow the equation

$$
C_{t}-\mu\left(A_{t}+H_{t}\right)+e_{t}
$$

where $H_{t}$ is human wealth, should be stationary. Any deviation fron the long run equilibrium relationship is stationary and short-lived. If current income affects consumption, and is itself not stationary, then the error term in equation 9 will not be stationary. Rather, the equilibrium relationship will be of the form:

$$
C_{t}=\mu\left(A_{t}+H_{t}\right)+\lambda Y_{t}+e_{t}
$$

i.e., consumption will be colntegrated with assets and income. If interest rates matter, $\mu$ will change over time, and there need be no cointegrating relationship between consumption and assets.

We examine the relevance of the additional explanation of the corporate veil mentioned at the beginning of this section by estimating consumption functions similar to equations 9 and 10 . If wealth is decomposed into its corporate, human, and noncorporate components, then we can relax the assumption that the propensities to consume from these are equal. ${ }^{24}$

If we difference equation 10 we obtain:

$$
\Delta C_{t}-\mu\left(\Delta A_{t}+\Delta H_{t}\right)+\lambda \Delta Y_{t}+e_{t}-e_{t-1}
$$


The presence of et-1 could lead to inconsistent estimates because it is correlated with the explanatory variables. An alternative approach if consumption, assets and income are colntegrated, is to substitute the lagged estimate of the error from equation 10 in as a proxy for $e_{t-1}$. In this "error-correction" model, we can also obtain consistent estimates of the coefficients on assets because the remaining error is orthogonal to the beginning of perfod explanatory variables. ${ }^{25}$ For continuity, we exclude after-tax dividends from disposable income and include these separately in the regression. Notice that in these regressions, the coefficient on dividends no longer reflects simply the exlstence of a corporate veil. Actual current dividends are likely to include new information about future income and hence current wealth as well. The same is true of actual disposable income. However, our focus in this section is not on these coefflclents, and the wealth coefficients should not be affected, since consumption responses to new information are assumed to be orthogonal to beginning of period wealth.

\section{B. The Data}

We construct our financlal asset measure from the quarterly Flow of Funds tables supplied by the Board of Governors of the Federal Reserve Bank, ${ }^{26}$ Noncorporate wealth Includes total financial assets net of corporate equities. and owter occupied housing. From this we subtract total liabilities net of Installment consumer credit. This is consistent with our exclusion of durables from our consumption measure, which is the same as that used in previous sections. Beginning of period values are used for all wealth variables. Corporate wealth is item 26 in the Flow of Funds table, "corporate equities". Our measure of human wealth is the present discounted value of future expected after tax labor earnings, calculated as a rolling forecast. 
These earnings are discounted at the arbltrary rate of .015 .27 specification tests indicated that this assumption was not crucial to the results. The time period considered is 1952-85.28 Preliminary testing indicated that all of the variables used are difference stationary.

\section{Results}

Table 6, Fow one, gives the result of the estimation of equation six using quarterly data, splitting off corporate equites and not imposing equality of wealth coefficients. The coefficlents on human wealth and noncorporate wealth are very similar, but the coefflclent on corporate wealth is small and negative. The test for colntegration is essentially a test for the nonstationarity of the error term, 1.e., In the simplest case, a test of the null hypothesis the errors are first-order autocorrelated with a unit root. Following Sargan and Bhargava (1983), we test the null that the Durbin-Watson statistic is zero. The Durbin-Watson statistic is a very low . 316 , which is close to the 5 percent critical value of the test of . 28,29 since the relevant critical value depends upon the data used, this can only be interpreted as weak evidence of cointegration. Two further tests of cointegration shed more light on the issue. The Dickey-Fuller and augmented Dickey-Fuller tests reported in Table 8 , Row 1 , both accept noncointegration of assets and consumption. Row 2 of table 6 presents an estimate of this model wh disposable income and dividends included. The coefficients on noncorporate assets and human wealth are somewhat smaller, and more plausible. The coefficlent on corporate equities is again small and negative. The Inclusion of these variables has increased the Durbin-Watson statistic to $.65{ }^{30}$ leading to a clear conclusion that these varlables are colneegrated. The Dickey Fuller and augmented Dickey fuller tests both accept cointegration 
at the 10 signiflcant level. (The 108 critical values from Engle and Yoo (1987) are 4.26 and 4.06 respectively). Row 3 contains the estimates of the differenced error correction model. One lag of the error correction term is reported since no further lags were found to be significant in this specification. With the exception of the coefficients on corporate equities and dividends, the coefficients are all smaller. The large drop in the human wealth coefficient may well reflect the nolsiness of our imputation method (see footnote 24 ).

Table 7 presents results for the same model using annual data. These results are quite similar to those based on quarterly data. 31 The pure lifecycie model rejects cointegration, and the inclusion of income leads to the acceptance of cointegration. 32

The most startling conclusion in both sets of regressions is that the aggregate marginal consumption out of corporate equities is so close to zero. 33,34 As already suggested, this could simply be a reflection of a declining marginal propensity to consume as wealth increases, combined with the high position in the income distribution of shareholders. The distribution of corporate wealth is indeed more skewed than that of noncorpozate wealth. Row 2 of Table 1, again taken from the 1983 Survey of Consumer Finances, shows the percentage of noncorporate wealth held by different strata of the fncome distribution. Contrasting this with the distribution of corporate equities depicted in row 1 , it is clear that the distribution of noncorporate wealth is more equal, especially in the top brackets. Strong evidence of a declining marginal propensity to consume out of asset wealth is supplied in Hoyt (1988), who shows that differences in the ratio of wealth to permanent income across income classes grow dramatically over the life cycle. Hoyt concludes that this indicates a much higher saving 
propensity among the wealthy. Other evidence of different propensities to consume across the income distribution is supplied in Drobny and Hall (1987). who use a relative tax varlable to identify distributional effects in an aggregate consumption function. They find that the marginal propensity to consume is much higher among low rate, l.e., low Income, taxpayers. ${ }^{35}$

Given the existing evidence of differing propenstities to consume among income classes, combined with the right skewed distribution of corporate wealth, one may explain the very low observed coeffictent on corporate wealth without requiring the presence of a corporate veil, as we have defined ic. This explanation is entirely consistent with our refection of the corporate veil in section II, because the previous experiment of altering dividend policy holds constant the distribution of wealth across the population, while the current approach need not. Nevertheless, even without a corporate veil, such a low coeffleient could still imply important consumption effects of shifts in the distribution of Income away from corporate shareholders. However such distributional effects have little to do with the separate existence of corporate enticles and depend very much on the particular policy experiment being envisaged.

\section{Concluston}

Th1s paper has used the modern theory of the consumer to devise a new test for the exiscence of the corporate vell. We find evidence that consumption is not excessively sensitive to fluctuations in dividends. reconfirmlng the view that shareholders successfully plerce the corporate veil. This finding is corroborated by other results suggesting that the significant excess sensitivity of current consumpton to other forms of income is due to liquidity constraints which, unllke lrrationality and myopia, cannot 
plausibly be associaced with consumption from corporate equity wealth.

We find very.little consumption from corporace assets in our consumption functions. This could be interpreted as evidence for a corpozate veil, However, one may also explain this as representing the presumably very low propensity to consume of shareholders, 77 of whom are in the top $5 \%$ of the income distribution. For many purposes, this distinction could be important. Future research, perhaps using panel data to isolate differences in propensity to consume from various assets, should examine these distributional issues. more closely. 


\section{Data Appendix}

The varlables used in our analysis are constructed as follows

(all variables not taken from the Flow of Funds tables are taken from the NIPA section of the Citibase dataset):

1) Consumption is personal consumption expenditures on nondurables and services.

2) Disposable income is broken down into Its capital and labor components by assigning proprietors' income and personal income taxes to each according to its factor share. Dividends are also converted to after-tax values in this way. Capital Income Includes interest payments. Labor income also includes wages and salaries, other labor Income and transfer payments.

3) Human wealth is the present discounted value of all future labor income (as defined above), and is calculated as a simple unfvarlate Eorecast of labor income. This forecast is constructed by first regressing full sample labor income on a constant and a trend, subtracting these, then performing an $8.1 a g$ VAR on the detrended serles. These VAR coefficlents are then used to forecast labor income given period $t$ information, then the constant and trend are added back in.

4) Corporate wealth is item 26 of the FoF sector balance sheets for households. As there is a separate entry for pension fund reserves (item 30), our variable excludes equities held by pension funds. Such pension assets are included in our measure of noncorporate wealth,

5) Noncorporate wealth is also taken from the Fof sector balance sheets for households. It equals owner occupied housing (item 4) plus total financial assets (1tem 11). less corporate equities (1tem 26) and total liabilities net of installment consumer credit (1tem 35 minus item 40). We exclude installment consumer credit and consumer durables for consistency with our 
consumption definition, which excludes durabies.

6) The interest rates used are quarterly averages of the 6 -month and 3 -month treasury bill rates. 


\section{Footnotes}

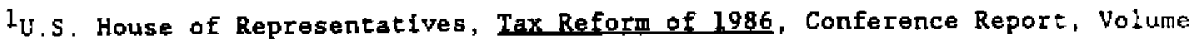
II, September 18, 1986, Table A 1.

2 "Tax Reform Requires Gramm-Rudman-hollings", Data Regources U,S Revlew, September, 1986, P. 17.

${ }^{3}$ Even with dividend taxes present, consumption should change only to the extent that the dividend payment reduces the shareholder's wealth. This effect should be small, and under the "new view" of corporate equity valuation (Auerbach 1979) should be nonexistent. In any event, since the tests derived below examine the effects on consumption of changes in dividend policy, holding wealth constant, any effects on wealth of pure financial policy associated with taxes will be purged from the estimated consumption response. ${ }^{4}$ Anocher possible channel for increased consumption effects would be wealth induced changes associated wth the shift in the tax burden. While there is a plausible theoretical argument that the provisions of the 1986 Act should have increased the value of corporate shares (Auerbach, 1989), this does not seem to be the mechanism the authors have in mind. However, this ambiguity highlights the problem in identifying the source of the perceived impact on consumption.

${ }^{5}$ For further evidence of the existence of the corporate veil see Bhatia (1979), or Hendershott and Peek (1987). For recent evidence against the cotporate veil see von Furstenburg (1981).

${ }^{6}$ Indeed, corporate savings is extremely difficult to define, For example, an increase in share repurchases and reduction in dividends appears as an Increase in corporate savings and a concomitant decline in personal savings. ${ }^{7}$ See Phillips (1986) for a recent discussion of spurious regressions. ${ }^{8}$ Several issues arise in considering whether it is acceptable to apply such 
"representaclve agent" equations to aggregate time serles data. Several authors have addressed these questions in the past with no clearly preferable alternative resulting. We do not clalm exception from the wswal criticisms, but neither do we view the current tests as especially sensitive to the types of aggregation bias involved, since the absence of a corporate veil implies a partictlar zero restriction for each individual's consumption behavior.

9 We are gratefu? to scott Hoyt for making this table avaliable to us. In principle, one would prefer a distribution of cosporate wealth by capital inoome classes, since Individuals with low tanglble wealth but high labor income would not be in a position to sell assets in ordez to consume. However this change would probably not alter the table's basic message significantly. $10_{\mathrm{Ar}}$ alzernative test suggested to us would consider whether responses of consumption to unanticipated dividends were zero once unanticipated changes in wealth were accounted for. In principle, this test should yield the same results as ours, but it has the considerable disadvantage of requiring us to observe unanticipated wealth changes. (In our spectfleation, this is not needed because observable lagged consumption is assumed to incorporate all information about wealth). Otherwise, conditional dividend surprises are likely to convey positive information about wealth, and contaminate the test. ${ }^{11}$ The use of doubly-lagged instruments is also appropriate to correct for the presence of transitory consumption. If transitory consumption is white noise, then it will also cause differencing to introduce an MA (1) error component. 12 Alternative spectfications using an after tax interest rate $y$ leldet virtually identical results and are not reported.

${ }^{13}$ This variable is only calculated (and only makes sense) annually, so in quarterly regressions the annual value for the corresponding year is used. ${ }^{14}$ In the regressions presented, the first-stage $\bar{R}^{2}$ values for the changes in 
dividends are in some cases higher than those for other forms of disposable incone - For example, in equation (4) of Table 2, the $\bar{R}^{2}$ is .06 for labor income, .05 for non-dividend capital income, and .13 for dividends. For equation (4) of Table 3 , the corresponding values are $.33, .17$ and, 28 . The annual estimates using doubly lagged instruments were similar to those reported in table 3, except for the coefficlent on dividends which was slighty negative. The fit of the first stage regressions using doubly lagged 1nstruments were quite poor, however, making the power of our test questionable. While aggregation problems most definitely still exist when using annual data, we report our estimates using singly lagged variables since these results are moderately more favorable to the existence of the corporate veil.

${ }^{15}$ In this light, it should be unsurprising that application of the HayashiSims (1987) correction for serlal correlation also had little impact on our findings. For this reason, we do not report them.

$16_{\text {We }}$ investigated a second alternative explanation for the insignifleance. that dividend changes in general might.have listle influence on consumption, by including dividend surprises in the second stage regression. We found the coefficient on unexpected dividends to be positive and significant. ${ }^{17}$ Campbell and Mankiw (1987), p. 32.

18 Actually, consumer behavior in such a model would be different in the tranition years between states, perhaps making a four state model the proper specification. Unfortunately, the addition of two more states greatly increases the computational burden and will be pursued at a later date. ${ }^{19}$ The basic idea is that the model is simply a mixture of two normal distributions, with the relative welght of each depending on all information up to time $T$ and the Markov probabilities. The algorithm passes through the 
data, using new information to recalculate the weights giver each distribution at each tome period.

20 The interest rate used is the annual average of quarterly 3 -month $T$-bill Iates.

2 For example, the unconditional probability of being in state 1 is: p21/(p12+p21), See Chiang for more detalls.

22 The differential reported is the average rate on short term commercial loans minus the prime rate, taken from the Federal Reserve Bulletin. We were urable to obtain a full series of another alternative measure of credit tightness attributable to Jaffee (1971). We interpret the relatively low differential during the 1960 s credit crisis as reflective of the well known quantity rationing in lending markets which occurred at that time, most notable the credit crunch of 1966 . In an alternative specification, which interacted the differential with income in an Euler equation, we found that the interaction. term had the correct $s$ gn but was not significantly different from zero. This is perhaps a reflection of the noisiness of the measure during the $1960 \mathrm{~s}$ 23 This assumes, of course, that they are both the same order of integration. All of the variables we use are integrated of the flrst order, or I(1). 24 since equations 6 and 7 also hold in differences, one wight also make inferences about the relative speeds of adjustment to changes in different forms of wealth by comparing the estimates from the levels regressions to those using differences. Since differencling is equivalent to passing the data through a filter which gives little weight to the low frequencies in the data, one would interpret the differenced estimates as "short run" coeffleients and the leveis estimates as the long run coefficients. However, given the errors with wich noncorporate assets and, especially, hum wealth are computed, one would also expect differences to depress the caefficients of the variabies. 
Separating these two effects (errors in variables and lagged adjustments) is not a simple task.

${ }^{25}$ The error correction coefflclent can also be interpreted as represenring an estimate of $(\rho-1)$, where $\rho$ is the first order serial correlation coefficient from the levels regression.

${ }^{26}$ The quarterly foF data was taken from the "Household Net Worth" tables published by the Board of Governors of the Federal Reserve Board, March, 1988. ${ }^{27}$ This value of the discount rate might be slightly lower than the actual rate. Increasing the discount rate translates into a slightly higher coefficient on human wealth in our regression. Following Hayashi (1982), it is possible to construct a model to estimate the discount rate of human wealth. Our estimates of Hayashi's model were very unreliable, however, and quite sensitive to the detrending technfque and convergence criterion used. Because of this, we omit reporting of these estimates in this paper.

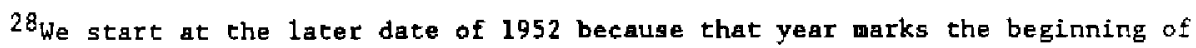
the availabillty of the quarterly wealth numbers from the fof cables. ${ }^{29}$ The choice of the proper test is quite a complicated issue. We use the Durbin-latson test because of its ease of computation and intuitive appeal. The Dickey-Fuller and augmented Dickey-Fuller tests are also reported. ${ }^{30}$ The 10 z critical value reported in Engle and Yoo (1987) for a higher order model is .46 for sample s1ze 100 .

31 For the annual regressions, wo also tried 1ncluding estimates of social security wealth, kindly supplied by Selig Lesnoy of the Soclal Security administration. However, this variable was computed only through 1974 . The resulting reduction in degrees of freedom may in part explain the erratic results that followed.

${ }^{32}$ The 10 eritical values in this case are .83 (DW), 4.42 (DF) and 3.85 (ADF). 
${ }^{33}$ This result is conslstent with earlier findings. Bean (1987) reports similarly small estrmates of the impact of corporate wealth on consumption. Blinder and Deaton (1985) report only an estlmate based on total net worth as a measure of wealth. Their estimate is approximately equal to out estimated coefficient for noncorporate wealth. In an alternative specification (not reported) that excluded human wealth, we obtafned a slightly higher coefficient (.015) for corporate wealth, but interpret this simply as evidence that the stock market is useful in predlcting future labor income. 340 ne potential explanation of this result is that the Induced relationship between owner-accupled housing and the imputed rent on such housing raises the coefficient on noncorporate assets above its true value. Leaving these two variables out of assets and consumption, respectively, actually leads to an increase in the gap between the two coefficients on assets. In equation (3), the coefficient on corporate wealth goes from .009 to .010 and that on noncorporate wealth rises from .039 to .058 . 35 Additional evidence on the effects of income redistribution on agregate consurption is supplied in Borooah and Sharpe (1986). 


\section{References}

Auerbach, A. J., 1979. "Wealth Maximization and the Cost of Capital," Quarterly Journal of Economics, August.

-..-., 1982. "Issues in the Measurement and Encouragement of Business Saving," in Savings and Government Rolicy, Federal Reserve Bank of Boston conference series no. 25, 79-100.

....., 1989. "Tax Reform and Adjustment Costs: The Impact on Investment and Market Value," Internatlonal Economic Review, forthcoming.

Bean, C.R., 1986, "The Estimation of 'Surprise' Models and the 'Surprise' Consumption Function," Review of Economic Studies 53, 497-516.

Blinder, A. S., and A. S. Deaton, 1985. "The Time Serles Consumption Function Revisited," Brookings Papers on Economic Activity 2, 465-511.

Borooah, V.K. and D.R. Sharpe, 1986, "Aggregate Consumption and the

Distribution of Income in the United Kingdom: An Econometric Analysis,"

Economic Journal, vol. 96.

Campbel1, J.Y., and N.G. Mankiw, 1987, "Permbnent Income, Current Income and Consumption," NBER working paper no. 2436.

Chiang, C. L., 1980. An Introduction to Stochastic Processes and Their Aonlicatlons, (Krieger, New York).

Cosslett, S.R., and L.F. Lee, 1985. "Serlal Correlaslon In Discrete Variable Models, Journal of Economecrlas, 27, 79.97.

Denison, E.F., 1958. "A Note on Private Saving," Review of Economics and Statisties, vol 40,761-67.

Drobny. A. and S.G. Hall, 1987. "An Investigation of the Long Run Properties of Aggregate Non-Durable Consumers' Expenditure in the UK, "mimeo. NIESR, Engle, R.F., and C.W.J. Granger, 1987, "Co-Integration and Error-Correction: Representation, Estimation and Testing," Econometrica 55, March, 251 . 
276.

Engle, R.F., and 8. S. Yoo, 1987, "Forecasting and Iesting in Co-Integrated Systems," Journal of Economerifics 35.

Feldştein, H, S, 1973. "Tax Incentives, Gorporate Saving and Capital Accumulation in the United States, "Journal of Public Economics 2(2). April, $159: 71$.

Flavin, M.A., 1981. "The Adjustment of Consumption to Changing Expectations about Future Income," Journal of Pol1tical Economy $89(5)$, October, 974 . 1009 .

Goldfeld, S. M., and R.E. Quandt, 1973. "A Markov Model for Switching Regressions," Journal of Econometrics. 1, 2-16.

Grossman, S.J., and R.J. Shiller, May 1981. "The Determinants of the Variabtlity of Stock Market Prices," American Econamic Reviei 71, 222 227.

Hal1, R. E., 1978. "Stachastic Implications of the Life Cycle-Permanent Income Hypothesis: Theory and Evidence," Journal of Political Economy $86(6)$, December, $971-987$.

....., 1988. "Intertemporal Substitution In Consumption," Journal of Politica1 Economy, 96, 339-357.

Hamilton, J.D., 1987. "A New Approach to the Economic Aralysis of Nonstationary Time Series and the Business Cycle," mimeographed, University of Virginia.

Hansen, L., and K. Singleton, 1983. "Stochastic Consumption, Risk Aversion, and the Temporal Behavior of Asset Returns," Journal of Polit1cal Economy 91, April, 249.65.

Hayashi, F,, 1982. "The Permanent Income Hypothesis: Estimating and Testing by Instrumental Variables," Journal of Political Economy 90, October, 895- 
916.

and C. Stms, 1983. "Nearly Efflclent Estimation of Time Serles Models with Predetermined, But Not Exogenous, Instruments," Econometrica 51. 783.798.

Hendershott, P. and J. Peck, 1987. "Private Saving in the U.S., 1950-1985," Working Paper 2294, NBER.

Hoyt, S., 1988. Wealth Accumulation in the 1983 Survey of Consumer Finances, Doctoral Dissertation, University of Pennsylvania. Jaffee, D.M., 1971. Gredit Rationing and the Commercial Loan Market, John Wiley 6 Sons, Inc.

Miller, M., and F. Modigliani, 1961. "Dividend Policy, Growth, and the Valuation of Shares," Journal of Bus1ness $34,411-33$.

Modigliani, F., and M. Miller, 1958. "The Cost of Capltal, Corporation Finance and the Theory of Investment," American Economle Review 48, 261 97.

Neftci. S.N., 1984. "Are Economic Time Serfes Asymmetric over the Business Cycle?," Journal of Political Economy, 92, $307-328$.

Phillips, P.C.B., 1986. "Understanding Spurious Regressions in Econometrics," Journal of Econometrics. 33, 311-40.

Poterba, J. M., 1987. "Tax Policy and Corporate Savings," Brookings Papers on Economic Activity, 2 .

Sargan, J,D. and A. Bhargava, 1983. "Testing Residuals from Least Squares Regression for Being Generated by a Gausstan Random Walk, "Econometrics, $51,153 \cdot 174$.

Von Furstenburg, G.M., 1981. "Saving," In Aaron, H., and J. Pechman, eds., How Taxes Affect Economic Behavior, Brookings, 327-90. 
Table 1

Percent of Total Wealth Held By Different Income Classes

(taken from the 1983 Survey of Consumer Finances)

\begin{tabular}{lccccccc}
$\begin{array}{l}\text { Incore Class } \\
\text { (percentile) }\end{array}$ & 0.10 & $10-25$ & $25-50$ & $50-75$ & $75-90$ & $90-95$ & $95-100$ \\
\&Corp.Wealth & .263 & .385 & 2.511 & 4.396 & 7.919 & 6.866 & 77.661 \\
\&other Wealth & 2.108 & 4.309 & 10.185 & 16.192 & 16.056 & 10.428 & 40.722 \\
\hline
\end{tabular}


Table 2

Euler Equation Estimates

(t statistics in parentheses)

dependent variable - log differenced consumption

(Quarterly, 1947:1 - 1986:1)

equation constant $\Delta y d_{t}^{e} \quad r_{t}^{e} \quad \Delta d i v_{t}^{e} \quad \Delta y k_{t}^{e} \Delta y l_{t}^{e}$

(5)

$\begin{array}{ccc}.002 & .431 & -.002 \\ (3.01) & (3.56) & (.137)\end{array}$

DW-2.34 $\quad \mathbf{R}^{2}=.111 \quad \overline{\mathbf{R}}^{2}-.093$

(6)

$\begin{array}{llll}.003 & .378 & -.010 & .065\end{array}$
(3. 20)
(2.89) $(-.503)$
(1.16)

$\mathrm{DW}-2.39 \quad \mathrm{R}^{2}=.121 \quad \mathrm{R}^{2}=.095$

(7)

$\begin{array}{llllll}.004 & & -.058 & .056 & -.085 & .458 \\ (4.15) & & (-2.45) & (1.17) & (-1.09) & (3.67)\end{array}$

$\mathrm{DW}-2.27 \quad \mathrm{R}^{2}-.177 \quad \dot{\mathbf{R}}^{2}=.145$

Notes: All variables, except the real interest race, expressed as differences of the logs of population-deflated variables. 
Table 3

Euler Equation Estimates

(t statistics in parentheses)

dependent varlable - log differenced consumption

(Annual, 1947 - 1986)

equation constant $\Delta y d_{t}^{e} \quad r_{t}^{e} \quad \Delta \operatorname{div}_{t}^{e} \quad \Delta y k_{t}^{e} \quad \Delta y l_{t}^{e}$

(5)

$.005 \quad .572 \quad-.017$
(2.39)
$(5.42) \quad(-.284)$

$D W=2.21 \quad \mathrm{R}^{2}=.576 \quad \overline{\mathrm{R}}^{2}=.537$

(6)

$\begin{array}{lccc}.008 & .554 & -.030 & .022 \\ (2.414) & (4.888) & (-.453) & (.463)\end{array}$

$\begin{array}{lll}D W-2.28 & R^{2}=.586 & \bar{R}^{2}=.527\end{array}$

\begin{tabular}{|c|c|c|c|c|c|c|}
\hline (7) & .011 & . & $=.152$ & .025 & .012 & .492 \\
\hline & $(2.229)$ & . & $(-2.951)$ & $(0.555)$ & $(.169)$ & $(4,832)$ \\
\hline
\end{tabular}

$D W=2.36 \quad R^{2}=.693 \quad \bar{R}^{2}-.631$ 
Table 4

Maximum Likelihood Estimation of Switching Regimes Model dependent varlable is $\mathrm{log}$ change of consumption.

t statistics are in parentheses

\begin{tabular}{lcccc}
\hline & $I_{t}$ & $\Delta y_{t-1}$ & $\sigma_{1}$ & $P_{11}$ \\
\hline State 1 & .047 & -.023 & 1.079 & .896 \\
& $(.60)$ & $(=.27)$ & $(7.52)$ & $(2.28)$ \\
State 2 & 082 & .526 & .510 & .743 \\
& $(1.18)$ & $(6.07)$ & $(3.87)$ & $(2.04)$ \\
Log Likelihood-53.79 & & & \\
\hline
\end{tabular}


Table 5

Conditional Probability of being in the Constrained state

\begin{tabular}{|c|c|c|c|}
\hline Year & Prabability & Credit Crisis & Average-Prime Rate \\
\hline 1949 &. .000 & & .70 \\
\hline 1950 & .000 & & .64 \\
\hline 1951 & .000 & & .75 \\
\hline 1952 & .039 & & .50 \\
\hline 1953 & .235 & & .53 \\
\hline 1954 & .000 & & .54 \\
\hline 1955 & .000 & & .47 \\
\hline 1956 & .023 & & .26 \\
\hline 1957 & .011 & & .10 \\
\hline 1958 & .270 & & .72 \\
\hline 1959 & .000 & & .54 \\
\hline 1960 & .041 & . & .38 \\
\hline 1961 & .245 & . & .50 \\
\hline 1962 & .097 & & .50 \\
\hline 1963 & .193 & & .50 \\
\hline 1964 & .000 & & .50 \\
\hline 1965 & .489 & & .52 \\
\hline 1966 & .739 & $\star$ & .40 \\
\hline 1967 & .637 & $\star$ & .36 \\
\hline 1968 & .574 & $\star$ & .40 \\
\hline 1969 & .646 & * & .25 \\
\hline 1970 & .668 & $\star$ & .57 \\
\hline 1971 & .257 & & .60 \\
\hline 1972 & .480 & & .57 \\
\hline 1973 & .618 & $\star$ & .27 \\
\hline 1974 & .000 & & .47 \\
\hline 1975 & .000 & & .40 \\
\hline 1976 & .008 & & .75 \\
\hline 1977 & .160 & & .85 \\
\hline 1978 & .314 & & .50 \\
\hline 1979 & .328 & & -.33 \\
\hline 1980 & .896 & * & 2.49 \\
\hline 1981 & .980 & $\star$ & 1.12 \\
\hline 1982 & .951 & $*$ & 2.25 \\
\hline 1983 & .749 & $*$ & -.48 \\
\hline 1984 & .107 & & .41 \\
\hline 1985 & .000 & & -.03 \\
\hline
\end{tabular}




\section{Table 6}

Estinates of Consurption from Wealth in Levels and Differences

(t statistics in parentheses)

Dependent variable - Quarterly Consumption

\begin{tabular}{lllll}
\hline Constant Human Wealth NC-Wealch Corp-Wealth YD Div \\
\hline
\end{tabular}

1) Quarterly levels:

$\begin{array}{lccc}.014 & .100 & -109 & -.016 \\ (.351) & (29.2) & (18.3) & (-4.31)\end{array}$

$D W=.316 \quad R^{2}=.99 \quad$ d.f. $=.2 .75 \quad$ a.d.f $=3.06$

2) Quarterly levels:

$\begin{array}{cccccc}.286 & .044 & .067 & -.001 & .358 & .307 \\ (8.55) & (9.46) & (12.55) & (-.319) & (13.65) & (.905)\end{array}$

$D W=.646 \quad R^{2}=.99$ d.f. $=-4.56$ a.d.E. -4.51

3) Quarterly differences:

$\begin{array}{cccccc}.019 & .007 & .027 & .006 & .243 & 1.56 \\ (3.56) & (.302) & (1.91) & (1.24) & (6.57) & (2.90)\end{array}$

DWh-1.82 $R^{2}=.49$ error correction parameter-.161 (-2.07) 
Table 7

Estimates of Consumption frow Wealth in Levels and Differences

( $c$ statistics in parentheses)

dependent variable - Annual Consumption

Constant Wwan Wealth NC-Health Corp-Wealth YD Div

1) Amnual levels:

$\begin{array}{lccc}-.042 & .105 & .104 & -.017 \\ (.092) & (14.29) & (7.99) & (-2.03)\end{array}$

$D N=.954 \quad R^{2}=.99 \quad$ d. E. $=-2.44$ a.d.E. $=-2.73$

2) Annual levels:

$\begin{array}{cccccc}.286 & .039 & .054 & -.005 & .612 & .817 \\ (3.73) & (3.64) & (4.70) & (-.698) & (6.87) & (1.09)\end{array}$

$D t, i=I .32 \quad \dot{R}^{2}=.99$ d.f. $=-3.43$ a.d. $f .=-4.08$

3) Annual differences:

.034

$-.007$

(1.46)

$(-.260)$

.039

(1.89)

$(1.25)$

.412

.933

$(5.94)$

(. 438$)$

$0 W=1.929 \quad \mathrm{R}^{2}-.86$ error correction parameter $=-.813(-3.19)$ 